\title{
Impact of physical and enzymatic cell wall opening on the release of pre- gelatinized starch and viscosity forming potential of potato flakes
}

\author{
S. Reyniers ${ }^{a, *}$, N. De Brier ${ }^{a}$, S. Matthijs ${ }^{b}$, K. Brijs ${ }^{a}$, J.A. Delcour ${ }^{a}$ \\ ${ }^{a}$ Laboratory of Food Chemistry and Biochemistry, and Leuven Food Science and Nutrition Research Centre (LFoRCe), KU Leuven, Kasteelpark Arenberg 20, B-3001, \\ Leuven, Belgium \\ ${ }^{\mathrm{b}}$ Kellogg Company, Bio-Incubator 2, Gaston Geenslaan 2, B-3001, Leuven, Belgium
}

\section{A R T I C L E I N F O}

\section{Keywords:}

Potato flakes

Pre-gelatinized starch

Swelling power

Amylose degree of polymerization

Pasting behavior

\begin{abstract}
A B S T R A C T
Potato flakes (PFs) are used in instant foods. They contain pre-gelatinized starch which readily develops viscosity upon hydration. We here provide the first report on factors influencing their viscosifying potential. Swelling power (SP) $(r=0.719, \mathrm{p}<0.01)$ and mean particle size $(\mathrm{r}=-0.704, \mathrm{p}<0.05)$ mainly determine instant viscosity development of PF suspensions while short extractable extracellular amylose molecules [degree of

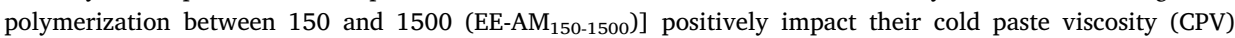
$(\mathrm{r}=0.717, \mathrm{p}<0.01)$ in Rapid Visco Analyzer (RVA) models. Cell wall opening by ball milling or cellulase treatments increased PF SP resulting in up to $75 \%$ higher RVA peak viscosity readings. Furthermore, the release of EE-AM $\mathrm{AM}_{150-1500}$ molecules increased CPV by about $30 \%$ since they readily associated upon cooling. Partial cell wall opening thus improves the viscosifying potential of PFs and expands their applicability in instant foods.
\end{abstract}

\section{Introduction}

The use of starch as functional ingredient in food systems in many instances relies on its ability to bind large amounts of water. When heated in water above a characteristic temperature, i.e. the gelatinization temperature, the molecular order of the native starch granules is irreversibly lost (Tan, Wee, Sopade, \& Halley, 2004; Tester \& Morrison, 1990). Upon gelatinization, starch crystallites melt and granules swell. This results in a large viscosity increase of the aqueous starch suspensions and progressive solubilization of starch molecules (Delcour \& Hoseney, 2010).

An alternative to heat treatment during food processing is to use pre-gelatinized starches as these have cold-water swelling properties (Dries, Knaepen, Goderis, \& Delcour, 2017). Cold-water swelling starches can be used in instant and convenience foods such as soups, sauces and puddings (Anastasiades, Thanou, Loulis, Stapatoris, \& Karapantsios, 2002; Majzoobi, Kaveh, Blanchard, \& Farahnaky, 2015; Mason, 2009). Pre-gelatinized starches are traditionally precooked, drum-dried and ground prior to their use in food applications (Chiu \& Solarek, 2009). One of the major drawbacks of such starches is that they have lower thickening ability upon heating in excess water than do their native counterparts (Anastasiades et al., 2002; Chiu \& Solarek, 2009). This has mainly been attributed to the loss of granular structure during their production (Rajagopalan \& Seib, 1992). Aqueous alcohol treatments at elevated temperature produce granular cold-water swelling starches with a V-type crystalline structure (Dries, Gomand, Goderis, \& Delcour, 2014; Dries, Gomand et al., 2017; Zhang, Dhital, Haque, \& Gidley, 2012). Such starches have superior thickening ability since the granular structure is preserved (Jane \& Seib, 1991).

Starch mainly consists of two $\alpha$-(1,4)-D-glucose polymers, the quasi linear amylose (AM) and the highly branched $[5-6 \% \alpha-(1,6)$ linkages] amylopectin (AP) (Buléon, Colonna, Planchot, \& Ball, 1998; Tester, Karkalas, \& Qi, 2004). Potato AM has a molecular weight (MW) of about $10^{6}$ and a degree of polymerization (DP) on a number average basis $\left(\mathrm{DP}_{\mathrm{n}}\right)$ of 4920 (Gomand, Lamberts, Derde et al., 2010; Takeda, Shirasaka, \& Hizukuri, 1984). Potato AP is much larger (MW $1.7 \times 10^{8}$ ) with a $\mathrm{DP}_{\mathrm{n}}$ value of 11,200 (Gomand, Lamberts, Derde et al., 2010; Takeda, Shibahara, \& Hanashiro, 2003). Starch swelling is mainly determined by AP (Tester \& Morrison, 1990). A unique feature is that, in contrast to what is the case for cereal starches, potato starch AP

Abbreviations: AP, amylopectin; AM, amylose; C*, close packing concentration; CPV, cold paste viscosity; DP, degree of polymerization; EE-AP, extractable extracellular amylopectin;

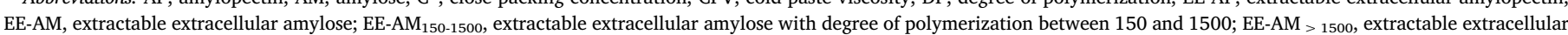

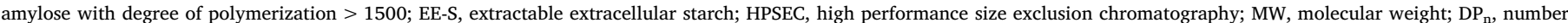
average degree of polymerization; PV, peak viscosity; PF, potato flake; RVA, rapid visco analyzer; SP, swelling power

* Corresponding author.

E-mail addresses: stijn.reyniers@kuleuven.be (S. Reyniers), niels.debrier@kuleuven.be (N. De Brier), stefaan.matthijs@kellogg.com (S. Matthijs), kristof.brijs@kuleuven.be (K. Brijs), jan.delcour@kuleuven.be (J.A. Delcour). 
contains a relatively high level of phosphate monoesters $(0.2-0.4 \%$ of the AP glucose units) (Takeda \& Hizukuri, 1982) which cause repulsion between adjacent chains (Bergthaller, 2004). This leads to rapid hydration, swelling, and high viscosity during heating. As a consequence, pre-gelatinized potato starches are highly suitable for instant applications (Yadav, Guha, Tharanathan, \& Ramteke, 2006).

Dehydrated potato (Solanum tuberosum L.) derivatives contain pregelatinized starch (Alvarez \& Canet, 1999; Gisaw, Asquith, Lai, Villagran, \& Cole, 2003; Villagran, Beverly, \& Williamson, 2011). They are produced by steam pealing, boiling, and mashing potatoes and subsequent drying (Lamberti, Geiselmann, Conde-Petit, \& Escher, 2004). During boiling, starch gelatinizes within the potato tissue (Kim \& Kim, 2015b). Although completely gelatinized, the starch granules are not fully disintegrated since the cell walls of the parenchyma cells in which they are embedded restrict their swelling during gelatinization (Lamberti et al., 2004). Boiling partially solubilizes the potato cell walls which mainly contain pectin [50-60\% of cell wall dry matter $(\mathrm{dm})]$ and cellulose $(30 \%$ of $\mathrm{dm})$. Blanching prior to boiling reduces the degree to which starch leaches from potato cells as it strengthens the parenchyma cell walls (van Dijk, Fischer, Beekhuizen, Boeriu, \& Stolle-Smits, 2002).

Dehydrated potato products thus contain cold-water swelling starch which readily develops viscosity upon hydration. They are available either as drum-dried potato flakes (PFs) or air-dried potato granules and are used in the production of instant potato soups, instant mashed potatoes and fried or extruded potato snacks (Alvarez \& Canet, 1999; Kim \& Kim, 2015a; Villagran et al., 2011). However, the parenchyma cell walls may retard or inhibit instant swelling upon hydration and hamper leaching of starch from potato cells (Kim \& Kim, 2015a, 2015b). PFs have a substantial portion of broken cells (40-60\%) since the cell walls are partially ruptured due to the shear during drumdrying (Villagran et al., 2011). In the process, part of the disintegrated starch granules enter the extracellular space (Alvarez \& Canet, 1999; Lamberti et al., 2004). Upon hydration, suspensions of PFs thus consist of potato cells and fragments thereof that are embedded in an extracellular starch matrix (Lamberti et al., 2004). These characteristics are believed to determine the functionality of PFs during food processing. However, to date, little is known about the composition of the extracellular starch fraction of PFs and its impact on gel formation.

Against this background, the present work not only set out to unravel the viscosifying properties of PFs in Rapid Visco Analyzer (RVA) model systems and, hence, their potential functionality in instant food systems but also to provide a rational basis for improving their viscosity development. Our effort includes physical and enzymatic treatments that disrupt the potato cells to impact on the release of pre-gelatinized starch and the pasting properties of PFs. The results provide a knowledge base for optimizing current and developing further applications of PFs in instant foods.

\section{Materials and methods}

\subsection{Materials}

Commercial PFs were kindly supplied by Clarebout (Nieuwkerke, Belgium), Lamb Weston/Meijer (Kruiningen, The Netherlands), Agrarfrost (Wildeshausen, Germany) and Farm Frites (Lommel, Belgium). All chemicals were at least of analytical grade and from Sigma-Aldrich (Bornem, Belgium) unless indicated otherwise. Isoamylase was from Pseudomonas sp. (0-8124), cellulase from Trichoderma reesei (C-8546), and the following peptidases were used: trypsin from porcine pancreas (T-4799), pepsin (P-6887) and papain (P3125). No pectinase side-activity was present in the cellulase. Furthermore, neither the cellulase nor the peptidases did contain $\alpha$ amylase side-activities (results not shown). Enzyme units (EU) mentioned are as defined by the supplier.

\subsection{Standard analyses}

Moisture and ash contents were measured according to AACC methods 44-15a and 08-12 (1999), respectively. PF protein contents $(\mathrm{N} \times 6.24)$ were determined by the Dumas combustion method, an automated protein analysis system (EAS, VarioMax N/CN, Elt, Gouda, The Netherlands) in line with AOAC Official Method 990.03 (1995). Starch contents were calculated as 0.9 times the glucose contents, which were determined by gas chromatography of alditol acetates obtained by acid hydrolysis, reduction and acetylation of the resulting glucose units as in Courtin, Van den Broeck, and Delcour (2000). Differential scanning calorimetry analysis and wide angle X-ray diffraction were executed as in Bosmans et al. (2012) and Dries et al. (2014), respectively, and showed that none of the PFs still contained ungelatinized starch (results not shown). Dietary fiber content was analyzed according to AOAC Official Method 991.43 (1995). The total uronic acid content of PFs was determined after acid hydrolysis as in Ahmed and Labavitch (1978). Hydrolysis of the pectin in PF samples $(500.0 \mathrm{mg})$ was with concentrated sulfuric acid $(8.0 \mathrm{~mL}, 95 \%$, VWR International, Leuven, Belgium) for $240 \mathrm{~min}$ in ice-water. To quantify the extractable uronic acids, PFs $(500.0 \mathrm{mg}$ ) were suspended in deionized water $(10.0 \mathrm{~mL})$, shaken $\left(150 \mathrm{~min}^{-1}, 30 \mathrm{~min}, 60^{\circ} \mathrm{C}\right)$ and then centrifuged $\left(2000 \mathrm{~g}, 15 \mathrm{~min}, 20^{\circ} \mathrm{C}\right)$. Total and extractable uronic acid contents were then analyzed as in Blumenkrantz and Asboe-Hansen (1973) using the chromogenic reagent meta-hydroxydiphenyl $(0.15 \%$ $\mathrm{w} / \mathrm{v})$ in $125 \mathrm{mM} \mathrm{NaOH}$. Extinctions were measured at $520 \mathrm{~nm}$. A galacturonic acid calibration curve $(0-0.5 \mu \mathrm{mol} / \mathrm{mL})$ was used to quantify the uronic acids. All analyses were performed in triplicate.

\subsection{Ball milling of potato flakes}

PFs $(180 \mathrm{~g})$ were ball milled in triplicate [500 revolutions per min (rpm)] for 5, 15, 30 or 60 min using a Retsch PM 100 planetary ball mill (Haan, Germany) equipped with a $500 \mathrm{~mL}$ stainless steel grinding jar and 6 stainless steel grinding balls $(20 \mathrm{~mm}$ in diameter). After every $5 \mathrm{~min}$ of actual milling, a $5 \mathrm{~min}$ rest was introduced to avoid extensive heat build-up in the jar. All analytical measurements were carried out for each technical replicate.

\subsection{Particle size distribution}

The cumulative volumetric particle size distributions (PSDs) of untreated and ball milled PFs were determined using a Malvern 2000 Mastersizer (Goffin/Meyvis, Hoeilaart, Belgium) which detects particles with diameters between $0.38 \mu \mathrm{m}$ and $2.000 \mathrm{~mm}$. The volumetric PSDs were calculated from the intensity of the scattered light based on the Fraunhofer theory (de Boer, de Weerd, Thoenes, \& Goossens, 1987). Average particle sizes were calculated in terms of the volume mean diameter, essentially as in Tzoumaki, Moschakis, Kiosseoglou, \& Biliaderis (2011).

\subsection{Microscopic analysis}

Cell walls in untreated and ball milled PFs (200 mg) were stained with Congo red $(1.0 \% \mathrm{w} / \mathrm{v})$ essentially as in Kim and Kim (2015a). Cellular structures were then studied with an Eclipse $80 \mathrm{i}$ epifluorescence microscope equipped with a digital sight DS-U2 camera and an Intenslight C-HGFI lamp (Nikon, Melville, NY, USA). Images were analyzed with Nikon NIS-Elements BR software.

\subsection{Swelling power}

The swelling properties of PFs were determined as in Eerlingen, Jacobs, Block, \& Delcour (1997). PFs suspended in deionized water $(0.25 \% \mathrm{w} / \mathrm{v})$ were heated at $60{ }^{\circ} \mathrm{C}$ [representing the consumption temperature of some instant food products such as soups and sauces 
(Kim \& Yoo, 2014)] for 30 min with intermittent shaking every 5 min. The suspensions were then centrifuged $\left(1000 \mathrm{~g}, 15 \mathrm{~min}, 20^{\circ} \mathrm{C}\right)$, the supernatants transferred to small test tubes and the sediments weighed. Carbohydrates in the supernatant were quantified by the method of Dubois, Gilles, Hamilton, Rebers, \& Smith (1956) using a glucose calibration curve $(0-1.1 \mu \mathrm{mol} / \mathrm{mL})$ and expressed as starch $(0.9 \times$ glucose). The close packing concentration ( $\left.\mathrm{C}^{*}\right)$ and swelling power (SP) at $60{ }^{\circ} \mathrm{C}$ were then calculated as follows:

$\mathrm{C}^{*}=\frac{\text { sample weight }(\mathrm{dm})}{\text { sediment weight }} \times 100$

$\mathrm{SP}=\frac{\text { sediment weight }}{\text { sample weight }(\mathrm{dm}) \times(100-\% \text { solubilized carbohydrates })} \times 100$

\subsection{Content and chromatographic separation of extracellular starch}

Starch was extracted by continuous shaking $\left(150 \mathrm{~min}^{-1}\right)$ for $30 \mathrm{~min}$ at $60{ }^{\circ} \mathrm{C}$ from untreated or ball milled PFs $(300.0 \mathrm{mg})$ suspended in $10.0 \mathrm{~mL} 200 \mathrm{mM}$ sodium phosphate buffer ( $\mathrm{pH} \mathrm{8.0)}$ and is further referred to as extractable extracellular starch (EE-S). After cooling to room temperature, the suspensions were centrifuged $(2000 \mathrm{~g}, 15 \mathrm{~min}$, $20^{\circ} \mathrm{C}$ ) and the carbohydrate contents of the supernatants determined according to Dubois et al. (1956) as outlined above.

\subsubsection{Protein degradation and starch debranching}

Since a refractive index detector (RID) would detect protein extracted along with the starch, a peptidase treatment was carried out prior to the chromatographic separation. Peptidase solution $(100 \mu \mathrm{L})$ containing $5.88 \% \mathrm{w} / \mathrm{v}$ trypsin, $0.40 \% \mathrm{w} / \mathrm{v}$ pepsin and $0.65 \% \mathrm{w} / \mathrm{v}$ papain in sodium phosphate buffer (pH 8.0, $200 \mathrm{mM}$ ) was added to $4.5 \mathrm{~mL}$ extract containing EE-S. To this mixture, $0.5 \mathrm{~mL} 100 \mathrm{mM}$ ethylene diamine tetraacetic acid (EDTA) disodium salt (VWR International) was added. It was then incubated for $5 \mathrm{~h}$ at $25^{\circ} \mathrm{C}$. In a next step, the peptidases were inactivated by heating $\left(10 \mathrm{~min}, 100^{\circ} \mathrm{C}\right)$. To $1.0 \mathrm{~mL}$ of the resulting samples, $0.9 \mathrm{~mL} 1.0 \mathrm{M}$ acetic acid (VWR International) was added to adjust the $\mathrm{pH}$ to 4.0. Starch was then debranched with isoamylase ( $400 \mathrm{EU})$ at $40^{\circ} \mathrm{C}$ for $48 \mathrm{~h}$, essentially as in Dries, Gomand, Delcour, and Goderis (2016), to allow separating long AM chains from short AP chains (Wang, Hasjim, Wu, Henry, \& Gilbert, 2014). After the first $24 \mathrm{~h}$ of incubation, $400 \mathrm{U}$ of isoamylase was again added to ensure complete debranching. After enzyme inactivation by heat treatment $\left(10 \mathrm{~min}, 100^{\circ} \mathrm{C}\right)$, samples were filtered $(0.45 \mu \mathrm{m}$, Thermo Scientific, Rockwood, TN, USA) and immediately analyzed by High Performance Size Exclusion Chromatography (HPSEC).

\subsubsection{Chromatographic separation}

HPSEC was used to determine the relative AM and AP levels and to study the chain length distribution of the debranched AM fraction.

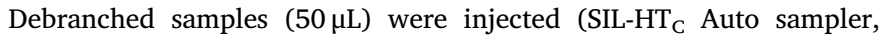
Shimadzu, Kyoto, Japan) into three TSK gel columns (G6000 PW $\mathrm{XL}_{\mathrm{XL}}$, G4000 $\mathrm{PW}_{\mathrm{XL}}$ and G3000 $\mathrm{PW}_{\mathrm{XL}}$ ) (Tosoh, Stuttgart, Germany) mounted in series on a modular Shimadzu SIL-HTc unit equipped with a LC-20AT pump, a DGU-20A5 degasser, a 10A RID operating at $40{ }^{\circ} \mathrm{C}$ and a column oven (CTO-20A, Shimadzu) at $60^{\circ} \mathrm{C}$. The flow rate was $0.5 \mathrm{~mL} /$ min and the eluent was a 10:9 (v/v) mixture of $200 \mathrm{mM}$ sodium phosphate buffer ( $\mathrm{pH}$ 8.0) containing $9.8 \mathrm{mM}$ disodium EDTA and 1.0 M acetic acid. Shodex P-82 pullulan standard solutions $(1.0 \mathrm{mg} / \mathrm{mL})$ (Showa Denko, Tokyo, Japan) with following MWs and corresponding DPs were injected $(50 \mu \mathrm{L}): 5.9 \times 10^{3}$ (DP 35), $11.8 \times 10^{3}$ (DP 70), $22.8 \times 10^{3}$ (DP 140), $47.3 \times 10^{3}$ (DP 290), $112 \times 10^{3}$ (DP 690), $212 \times 10^{3}$ (DP 1310), $404 \times 10^{3}$ (DP 2490), $788 \times 10^{3}$ (DP 4860) and $1600 \times 10^{3}$ (DP 9880). A third order polynomial relation was fitted between the logarithm of the MWs of the standards and the elution times. The HPSEC weight distribution chromatograms were divided into 3 regions based on the DP of the eluting molecules (Li, Fitzgerald,
Prakash, Nicholson, \& Gilbert, 2017). Components with DP $<150$ were defined as AP branches, while molecules with DP $>150$ were defined as AM chains. The relative amounts of AM and AP in the EE-S were determined as the area under the elution curve and expressed in arbitrary units (AU). The distribution of AM molecules was further divided into 2 regions with DP limits being: $150-1500$ and $>1500$ (Gomand, Lamberts, Derde et al., 2010). Each HPSEC analysis run included a reference PF sample for quality control reasons.

\subsection{Pasting properties}

The pasting of PF suspensions was studied with an RVA Super 4 (Perten Instruments, Hägersten, Sweden). PFs $(2.0 \mathrm{~g} \mathrm{dm})$ were premixed with $540 \mu \mathrm{L} 95 \%(\mathrm{v} / \mathrm{v})$ ethanol (Chem-Lab, Zedelgem, Belgium) to avoid excessive swelling prior to analysis. Deionized water was then added to obtain a total sample mass of $25.0 \mathrm{~g}$ (dm content of $8.0 \%$ ). The $\mathrm{PF}$ suspensions were equilibrated for $5 \mathrm{~min}$ at $50^{\circ} \mathrm{C}$, heated to $95^{\circ} \mathrm{C}$ at $9^{\circ} \mathrm{C} / \mathrm{min}$, held at $95^{\circ} \mathrm{C}$ for $8 \mathrm{~min}$, cooled to $50^{\circ} \mathrm{C}$ at $9^{\circ} \mathrm{C} / \mathrm{min}$ and held at $50^{\circ} \mathrm{C}$ for $5 \mathrm{~min}$. The stirring speed was $160 \mathrm{rpm}$.

\subsection{Cellulase treatment}

PFs (150.0 mg) suspended in $10.0 \mathrm{~mL} 100 \mathrm{mM}$ sodium acetate buffer (pH 5.0) were incubated in triplicate with cellulase $(0.10 \mathrm{U}$ per $\mathrm{mg} \mathrm{dm}$ flakes) at $40{ }^{\circ} \mathrm{C}$ for $1,2,4$ and $6 \mathrm{~h}$ while stirring at $130 \mathrm{rpm}$ to hydrolyze cellulose in PF cell walls. After centrifugation $\left(2000 \mathrm{~g}, 15 \mathrm{~min}, 20^{\circ} \mathrm{C}\right.$ ), the samples were heated $\left(10 \mathrm{~min}\right.$ at $\left.100{ }^{\circ} \mathrm{C}\right)$ to inactivate cellulase. The same treatments were also executed without cellulase addition. Quantification and chromatographic separation of the EE-S was executed essentially as in 2.7. The SP of PFs in the presence of cellulase was determined essentially as in 2.6. PFs were suspended in $100 \mathrm{mM}$ sodium acetate buffer (pH 5.0) and kept at $40^{\circ} \mathrm{C}$ for $30 \mathrm{~min}$. When studying the impact of cellulase on PF pasting, no ethanol was added to the PFs prior to RVA analysis and, instead of deionized water, $100 \mathrm{mM}$ sodium acetate buffer ( $\mathrm{pH}$ 5.0) was added to the PFs to obtain a total sample mass of $25.0 \mathrm{~g}$. Pasting properties were determined in duplicate. PF suspensions without cellulase served as control for analysis of SP and pasting properties.

\subsection{Statistical analysis}

All statistical analyses were conducted using JMP Pro 12 (SAS Institute, Cary, NC, USA). Data were analyzed with one-way analysis of variation (ANOVA) and Tukey multiple comparison test (significance level $\mathrm{p}<0.05$ ) to verify whether mean values were significantly different. Pearson correlation coefficients ( $r$ ) were calculated to determine correlations between PF physico-chemical properties. Principal component (PCA) and hierarchical cluster analysis (HCA) were used to select representative PF samples.

\section{Results and discussion}

\section{1. (Physico-)chemical characterization of potato flakes}

Table 1 gives a summary of the chemical composition, SP, level and composition of EE-S, and pasting properties of 12 untreated PF samples (numbered from 1 to 12 ). Starch $(77.2 \%-81.5 \%$ of $\mathrm{dm}$ ), protein $(7.4 \%-9.8 \%$ of $\mathrm{dm})$, dietary fiber $(6.7 \%-8.6 \%$ of $\mathrm{dm})$ and ash $(2.7 \%-3.7 \%$ of $\mathrm{dm})$ contents differed somewhat amongst the PFs investigated and were in line with published data (Kim \& Kim, 2015b; Yadav et al., 2006). The mean particle sizes of PFs, their SPs and peak viscosities at $50{ }^{\circ} \mathrm{C}$ in the RVA model system (PVs) ranged from 241 to $427 \mu \mathrm{m}$, from 27.9 to $34.0 \mathrm{~g} / \mathrm{g} \mathrm{dm}$, and from 1045 to $1755 \mathrm{mPa}$, respectively. The latter were significantly related to SP $(r=0.719$, $\mathrm{p}<0.01)$ as well as to mean particle size $(\mathrm{r}=-0.704, \mathrm{p}<0.05)$ (Supplementary data Fig. 1). In general, PFs with a relatively small 


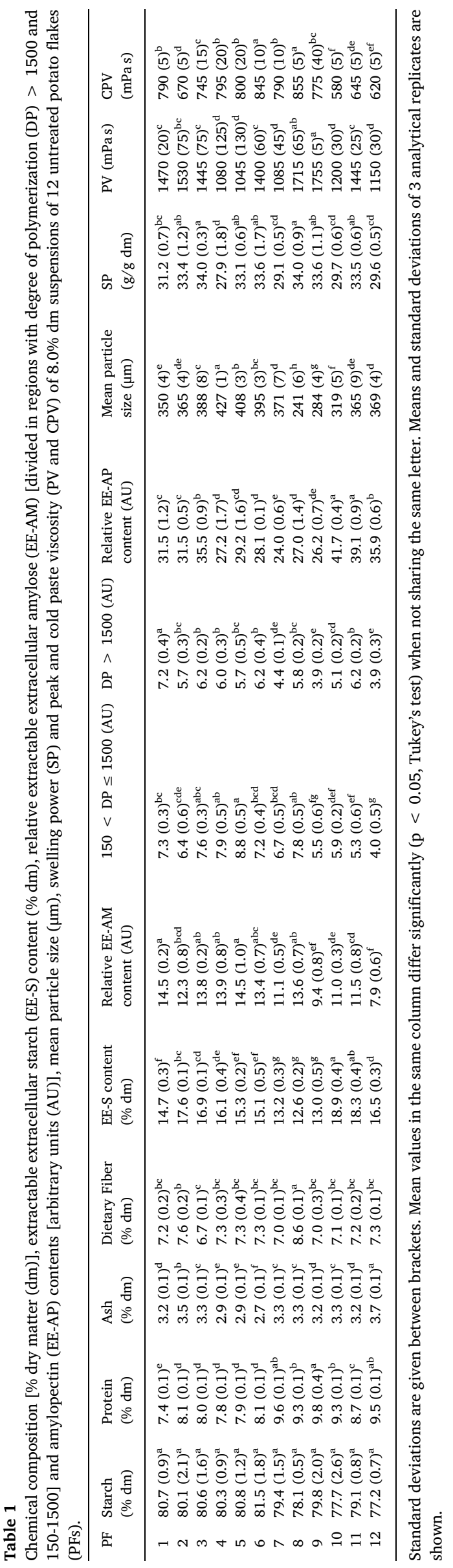

mean particle size and high SP exhibited enhanced instant viscosity development. The RVA profiles of PF suspensions also showed a viscosity peak during heating which originated from a second starch swelling due to (1) the higher water binding capacity of starch at higher temperatures (Gomand, Lamberts, Visser, \& Delcour, 2010), and (2) partial cell wall breakdown of potato cells during heating under continuous shear (van Marle et al., 1997). Cold paste viscosities (CPVs) ranged from 580 to $855 \mathrm{mPa}$.s and were not related to PV values. The formation of a continuous gel network when cooling starch suspensions is dictated by AM gelation (Delcour \& Hoseney, 2010; McGrane, Mainwaring, Cornell, \& Rix, 2004). Although the PFs in the present study had similar total starch contents, their EE-S contents ranged from $12.6 \%$ to $18.9 \% \mathrm{dm}$. Moreover, HPSEC separation of EE-S into extractable extracellular amylose (EE-AM) and extractable extracellular amylopectin (EE-AP) showed that relative EE-AM and EE-AP contents ranged from 7.9 to $14.5 \mathrm{AU}$ and from 26.4 to $41.7 \mathrm{AU}$, respectively. Although it has been suggested that the extracellular starch fraction mainly consists of AM (Escher, Rotach, Schweingruber, \& Solms, 1979; Lamberti et al., 2004), we here clearly showed that it contained substantial amounts of AP. Potato AP has a relatively high solubility in water due to it being partly phosphorylated (Singh, Singh, Kaur, Sodhi, \& Gill, 2003; Svegmark \& Hermansson, 1991). Last but not least, the relative contents of EE-AM molecules with DP 150-1500 (EE-AM ${ }_{150-}$ $\left.{ }_{1500}\right)$ and $\mathrm{DP}>1500(\mathrm{EE}-\mathrm{AM}>1500)$ ranged from 4.0 to $8.8 \mathrm{AU}$ and from 3.9 to $7.2 \mathrm{AU}$, respectively.

We here further observed that the $\mathrm{EE}^{-\mathrm{AM}_{150-1500}}$ contents were positively $(r=0.717, \mathrm{p}<0.01)$ correlated with CPV (Supplementary data Fig. 1) while EE-AM $>1500$ contents were not. Thus, higher levels of shorter EE-AM chains increased PF gel formation. It has earlier been reported that short AM chains have a high rate of AM association and, hence, gel formation (Chung \& Liu, 2009; Gidley \& Bulpin, 1989). The extractable AM chains with relatively high MW that are present in the extracellular space are probably less mobile during cooling and thereby limit the degree to which AM associates (Chung \& Liu, 2009).

To provide a rational basis for improving the viscosifying potential of PFs, HCA and PCA were combined to first select representative PF samples based on the above-mentioned characteristics (Supplementary data Fig. 2). HCA grouped the samples of PFs in four well-defined clusters. Next, a PCA plot was constructed based on three uncorrelated principal components of linear combinations of PF physico-chemical properties. It explained $83 \%$ of the total variation in $\mathrm{PF}$ characteristics. PFs 1, 4, 8 and 10 occurred in a different cluster (HCA) and covered the variation in PF characteristics (PCA). This subset of PF samples was here used to study the impact of additional cell wall breakdown by physical (ball milling) and enzymatic (cellulase) treatments on the release of starch (especially AM) and the pasting and gelation properties of PF suspensions in RVA models.

\subsection{Milling induced changes in potato flake morphology}

Both untreated and ball milled PFs had a unimodal particle size distribution (Supplementary data Fig. 3). Fig. 1 shows the cumulative particle size distributions. Ball milling PFs for $60 \mathrm{~min}$ significantly reduced their mean particle size from $350 \mu \mathrm{m}$ to $152 \mu \mathrm{m}$, from $427 \mu \mathrm{m}$ to $125 \mu \mathrm{m}$, from $241 \mu \mathrm{m}$ to $130 \mu \mathrm{m}$ and from $319 \mu \mathrm{m}$ to $154 \mu \mathrm{m}$ for PF 1,4 , 8 and 10, respectively. The resultant PF dimensions approximated the size of individual potato cells $(150 \mu \mathrm{m})$ (Bordoloi, Kaur, \& Singh, 2012). Microscopic images (Fig. 2) clearly showed that ball milling physically damaged the cells. As a result of $60 \mathrm{~min}$ of ball milling, the soluble uronic acid contents were $8-25 \%$ higher (Table 2). Taken together, ball milling disrupted the potato cells and partially solubilized their cell wall material.

\subsection{Swelling power}

Fig. 3 shows that ball milling caused the SP of PFs to be significantly 

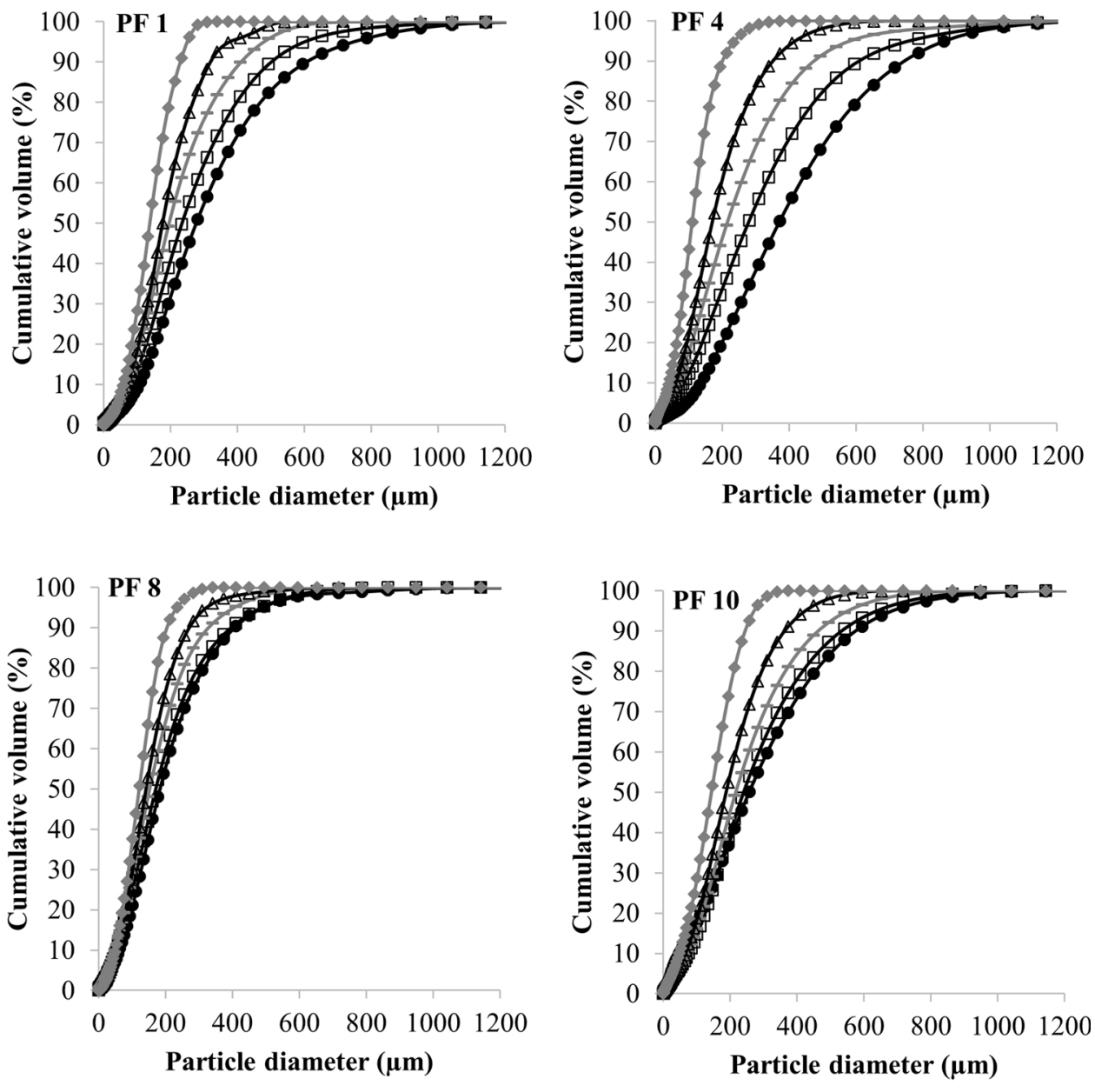

$\rightarrow$ Untreated $\square-5 \mathrm{~min}$ $15 \min$

$\neg 30 \mathrm{~min} \rightarrow 60 \mathrm{~min}$

Fig. 1. Particle size distribution of untreated and ball milled potato flakes (PFs) expressed as the cumulative amount of particles (volume\%) as a function of the particle diameter $(\mu \mathrm{m})$.

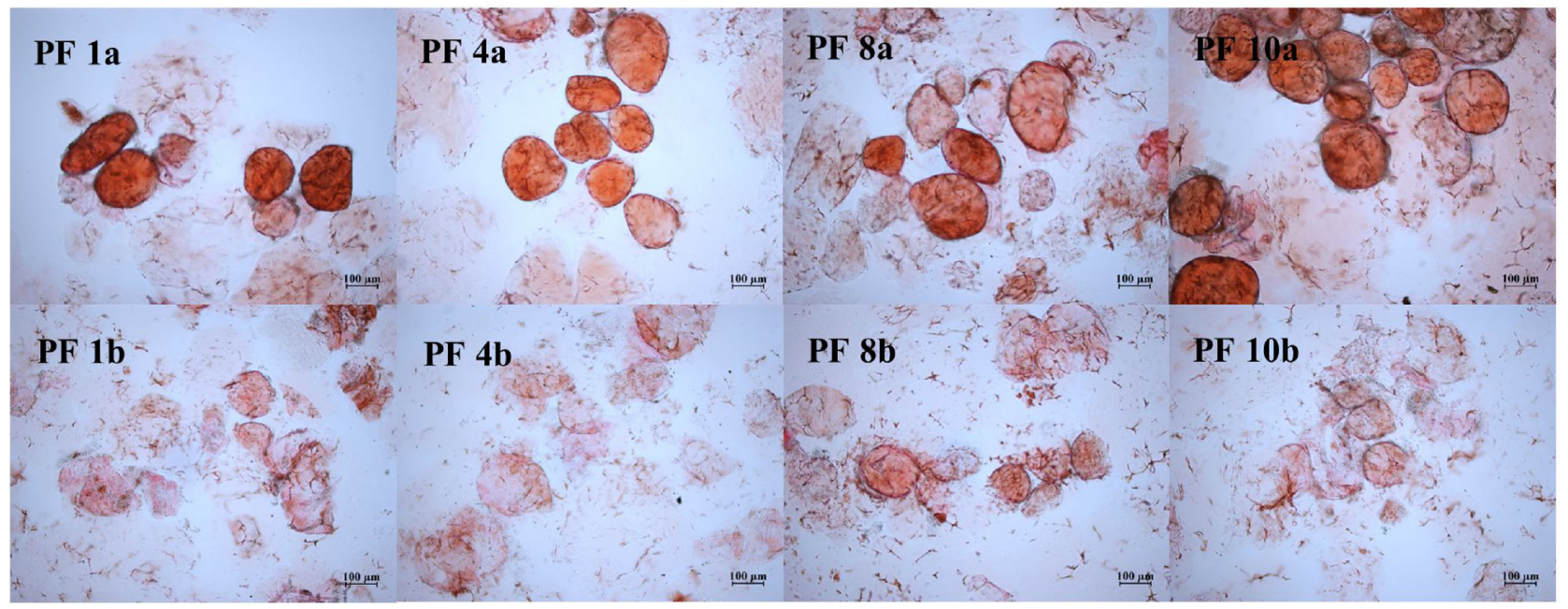

Fig. 2. Light microscopy images of (A) untreated and (B) ball milled (60 min) potato flakes (PFs) stained with Congo red (1.0\%, w/v). (For interpretation of the references to colour in this Figure legend, the reader is referred to the web version of this article.)

higher. As a result of 60 min of milling, the SP of PFs 1, 4, 8 and 10 had increased from 31.2 to $35.3 \mathrm{~g} / \mathrm{g} \mathrm{dm}$, from 27.9 to $37.3 \mathrm{~g} / \mathrm{g} \mathrm{dm}$, from 34.0 to $36.1 \mathrm{~g} / \mathrm{g} \mathrm{dm}$ and from 29.7 to $31.6 \mathrm{~g} / \mathrm{g} \mathrm{dm}$, respectively. Note the pronounced increase for PF 4. Kim and Kim (2015b) earlier suggested that intact parenchyma cell walls retard or limit swelling of pre- gelatinized starches when entrapped in their cellular matrix. We here indeed showed that partial opening of the PF cell walls by ball milling effectively improved their SP.

To further study the impact of cell wall breakdown on PF SP, the cellulose fraction was enzymatically hydrolyzed. Note that the SPs of 
Table 2

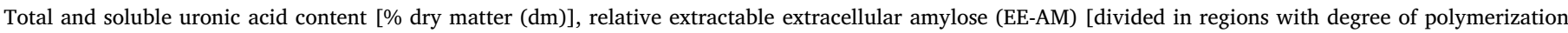

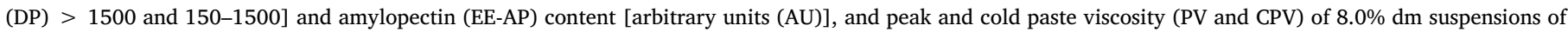
untreated and ball milled (5, 15, 30 and $60 \mathrm{~min}$ ) potato flakes (PFs).

\begin{tabular}{|c|c|c|c|c|c|c|c|c|}
\hline PF & & $\begin{array}{l}\text { Total uronic acid } \\
\text { content }(\% \mathrm{dm})\end{array}$ & $\begin{array}{l}\text { Soluble uronic acid } \\
\text { content }(\% \mathrm{dm})\end{array}$ & $\begin{array}{l}\text { Relative EE-AM } \\
\text { content (AU) }\end{array}$ & $150<\mathrm{DP} \leq 1500(\mathrm{AU})$ & $\mathrm{DP}>1500(\mathrm{AU})$ & $\begin{array}{l}\text { Relative EE-AP } \\
\text { content (AU) }\end{array}$ & $\begin{array}{l}\text { CPV } \\
\text { (mPa s) }\end{array}$ \\
\hline \multirow[t]{2}{*}{1} & Untreated & $2.02(0.09)$ & $0.56(0.02)^{\mathrm{b}}$ & $14.5(0.2)^{\mathrm{a}}$ & $7.3(0.3)^{\mathrm{a}}$ & $7.2(0.4)^{\mathrm{a}}$ & $31.5(1.2)^{\mathrm{b}}$ & $790(5)^{b}$ \\
\hline & $60 \mathrm{~min}$ & & $0.77(0.03)^{\mathrm{a}}$ & $14.6(0.1)^{\mathrm{a}}$ & $7.3(0.3)^{\mathrm{a}}$ & $7.3(0.8)^{\mathrm{a}}$ & $44.7(0.6)^{\mathrm{a}}$ & $865(15)^{\mathrm{a}}$ \\
\hline \multirow[t]{2}{*}{4} & Untreated & $1.52(0.12)$ & $0.40(0.01)^{\mathrm{a}}$ & $13.9(0.8)^{\mathrm{b}}$ & $7.9(0.5)^{\mathrm{b}}$ & $6.0(0.3)^{\mathrm{b}}$ & $27.2(1.7)^{\mathrm{b}}$ & $795(20)^{\mathrm{b}}$ \\
\hline & $60 \mathrm{~min}$ & & $0.54(0.04)^{\mathrm{a}}$ & $20.8(0.9)^{\mathrm{a}}$ & $12.8(0.5)^{\mathrm{a}}$ & $8.0(0.4)^{\mathrm{a}}$ & $37.1(2.1)^{\mathrm{a}}$ & $1040(5)^{\mathrm{a}}$ \\
\hline \multirow[t]{2}{*}{8} & Untreated & $2.35(0.06)$ & $0.65(0.01)^{\mathrm{a}}$ & $13.6(0.7)^{\mathrm{a}}$ & $7.8(0.5)^{\mathrm{a}}$ & $5.8(0.2)^{\mathrm{a}}$ & $27.0(1.4)^{b}$ & $855(5)^{b}$ \\
\hline & $60 \mathrm{~min}$ & & $0.71(0.01)^{\mathrm{a}}$ & $13.3(0.3)^{\mathrm{a}}$ & $7.7(0.2)^{\mathrm{a}}$ & $5.6(0.5)^{\mathrm{a}}$ & $34.5(0.8)^{\mathrm{a}}$ & $900(5)^{\mathrm{a}}$ \\
\hline \multirow[t]{2}{*}{10} & Untreated & $1.84(0.04)$ & $0.59(0.02)^{\mathrm{b}}$ & $11.0(0.3)^{\mathrm{b}}$ & $5.9(0.2)^{\mathrm{b}}$ & $5.1(0.2)^{\mathrm{a}}$ & $41.7(0.4)^{b}$ & $580(5)^{b}$ \\
\hline & $60 \mathrm{~min}$ & & $0.77(0.02)^{\mathrm{a}}$ & $12.1(0.5)^{\mathrm{a}}$ & $6.5(0.2)^{\mathrm{a}}$ & $5.6(0.4)^{\mathrm{a}}$ & $56.2(2.4)^{\mathrm{a}}$ & $610(5)^{\mathrm{a}}$ \\
\hline
\end{tabular}

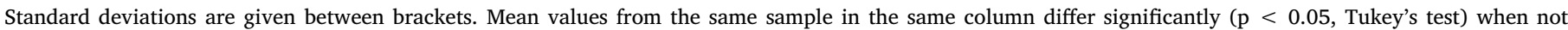
sharing the same letter. Means and standard deviations of 3 analytical replicates are shown.
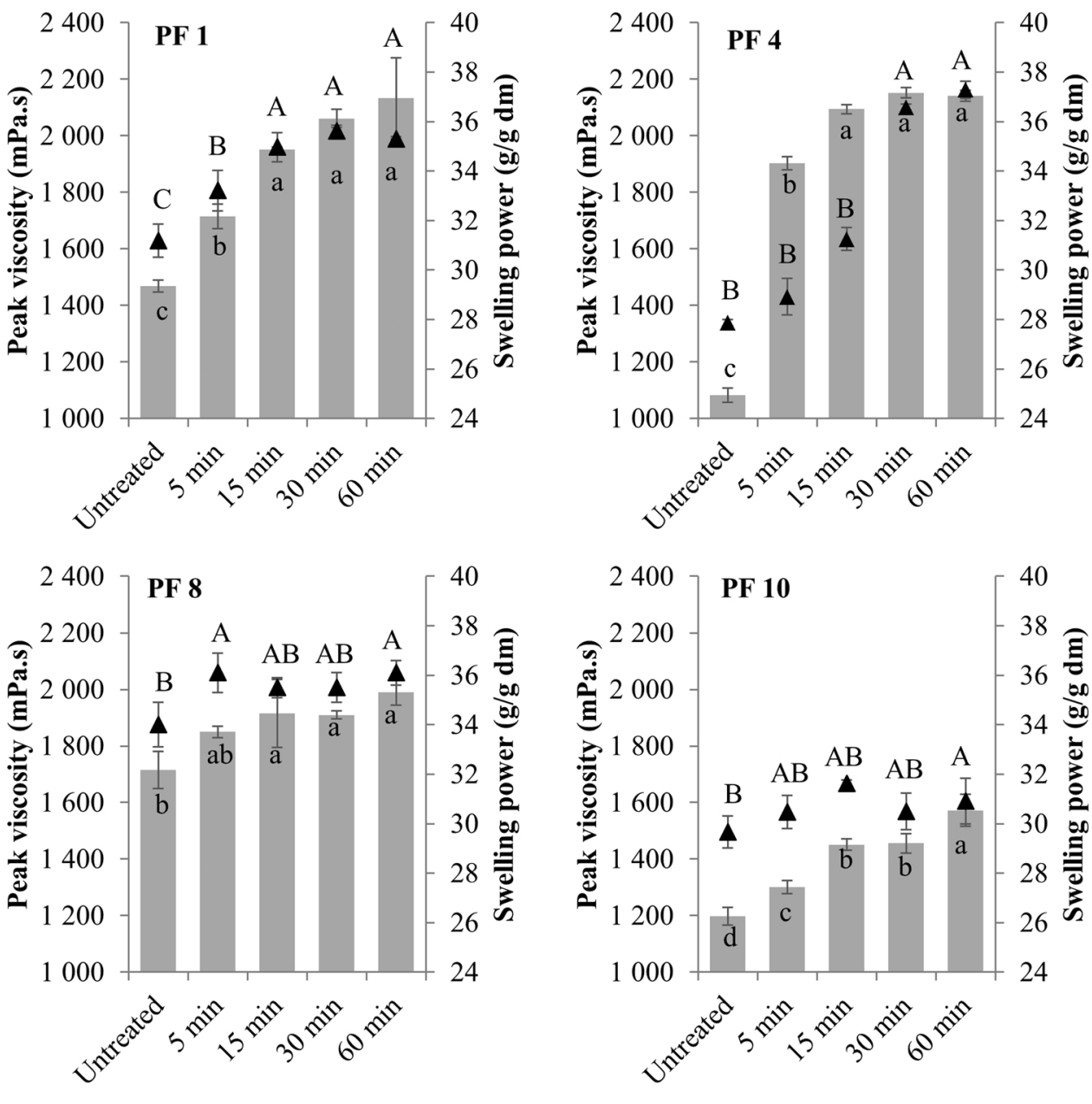

- Peak viscosity

$\Delta$ Swelling power

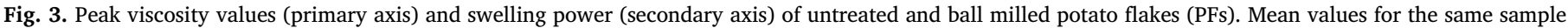
differ significantly ( $<<0.05$, Tukey's test) when not sharing the same upper (swelling power) or lower case (peak viscosity) letter.

the control samples (Table 3 , analyzed at $40{ }^{\circ} \mathrm{C}$ and $\mathrm{pH} 5.0$ for ensuring optimal cellulase activity) in this experiment were considerably lower $(15.9-17.7 \mathrm{~g} / \mathrm{g} \mathrm{dm})$ than those of the untreated samples shown in Fig. 3 (27.9-34.0 g/g dm, analyzed at $60{ }^{\circ} \mathrm{C}$ in deionized water). Cellulase treatment significantly increased PF SP by $7.1 \%$ (PF 8 ) to $14.9 \%$ (PF 10).

Taken together, physical and enzymatic cell wall breakdown improved starch and, hence, PF swelling properties.

\subsection{Extracellular starch}

Since the properties of the extracellular starch matrix dictate PF gelation (see 3.1), we here studied the impact of physical or enzymatic treatments on the EE-S contents and properties of PFs. Fig. 4 shows that increasing extents of ball milling resulted in gradually increasing EE-S contents. After 60 min of milling, the EE-S content of PFs 1, 4, 8 and 10 had significantly increased from 14.7 to $19.0 \% \mathrm{dm}$, from 16.1 to $22.7 \%$ $\mathrm{dm}$, from 12.6 to $15.7 \% \mathrm{dm}$ and from 18.9 to $24.9 \% \mathrm{dm}$, respectively. 
Table 3

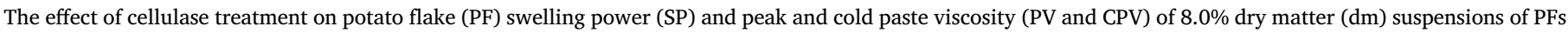

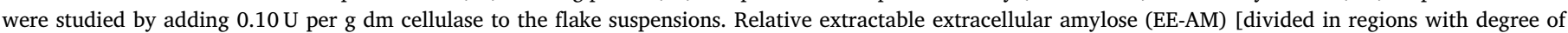

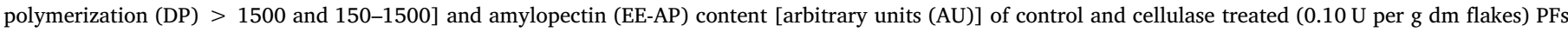
after $6 \mathrm{~h}$ of incubation are also listed.

\begin{tabular}{|c|c|c|c|c|c|c|c|c|}
\hline $\mathrm{PF}$ & & $\mathrm{SP}(\mathrm{g} / \mathrm{g} \mathrm{dm})$ & Relative EE- AM content (AU) & $150<\mathrm{DP} \leq 1500(\mathrm{AU})$ & $\mathrm{DP}>1500(\mathrm{AU})$ & Relative EE- AP content (AU) & PV (mPa s) & $\mathrm{CPV}(\mathrm{mPa} s)$ \\
\hline \multirow[t]{2}{*}{1} & Control & $17.7(0.2)^{\mathrm{b}}$ & $3.9(0.1)^{\mathrm{b}}$ & $1.5(0.1)^{\mathrm{a}}$ & $2.4(0.2)^{\mathrm{b}}$ & $21.7(0.7)^{\mathrm{b}}$ & $1285(30)^{\mathrm{b}}$ & $900(10)^{\mathrm{a}}$ \\
\hline & Cellulase treated & $19.4(1.0)^{\mathrm{a}}$ & $4.7(0.2)^{\mathrm{a}}$ & $1.7(0.1)^{\mathrm{a}}$ & $3.0(0.1)^{\mathrm{a}}$ & $32.2(1.2)^{\mathrm{a}}$ & $2080(100)^{\mathrm{a}}$ & $925(10)^{\mathrm{a}}$ \\
\hline \multirow[t]{2}{*}{4} & Control & $15.9(0.3)^{b}$ & $3.4(0.4)^{\mathrm{b}}$ & $2.2(0.2)^{\mathrm{b}}$ & $1.2(0.1)^{\mathrm{a}}$ & $13.4(0.5)^{\mathrm{b}}$ & $960(5)^{\mathrm{b}}$ & $880(5)^{b}$ \\
\hline & Cellulase treated & $18.1(0.5)^{\mathrm{a}}$ & $6.2(0.3)^{\mathrm{a}}$ & $4.6(0.3)^{\mathrm{a}}$ & $1.6(0.3)^{\mathrm{a}}$ & $25.4(1.1)^{\mathrm{a}}$ & $1705(10)^{\mathrm{a}}$ & $985(5)^{\mathrm{a}}$ \\
\hline \multirow[t]{2}{*}{8} & Control & $16.9(0.5)^{\mathrm{b}}$ & $2.7(0.5)^{\mathrm{a}}$ & $1.5(0.3)^{\mathrm{a}}$ & $1.2(0.3)^{\mathrm{a}}$ & $12.6(0.4)^{\mathrm{b}}$ & $1185(25)^{\mathrm{b}}$ & $815(5)^{a}$ \\
\hline & Cellulase treated & $18.1(0.4)^{\mathrm{a}}$ & $3.2(0.6)^{\mathrm{a}}$ & $1.7(0.2)^{\mathrm{a}}$ & $1.5(0.3)^{\mathrm{a}}$ & $21.6(0.3)^{\mathrm{a}}$ & $1495(5)^{a}$ & $820(5)^{a}$ \\
\hline \multirow[t]{2}{*}{10} & Control & $17.4(0.3)^{\mathrm{b}}$ & $3.8(0.2)^{\mathrm{a}}$ & $1.8(0.1)^{\mathrm{a}}$ & $2.0(0.1)^{\mathrm{a}}$ & $22.3(0.7)^{\mathrm{b}}$ & $690(25)^{\mathrm{b}}$ & $590(5)^{a}$ \\
\hline & Cellulase treated & $20.0(1.4)^{\mathrm{a}}$ & $3.9(0.1)^{\mathrm{a}}$ & $1.8(0.1)^{\mathrm{a}}$ & $2.1(0.2)^{\mathrm{a}}$ & $32.6(0.2)^{\mathrm{a}}$ & $1005(5)^{\mathrm{a}}$ & $605(5)^{\mathrm{a}}$ \\
\hline
\end{tabular}

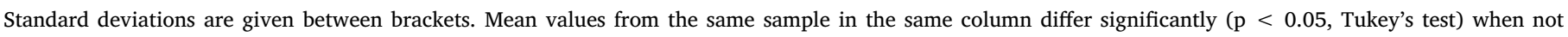
sharing the same letter. Means and standard deviations of 3 analytical replicates are shown.

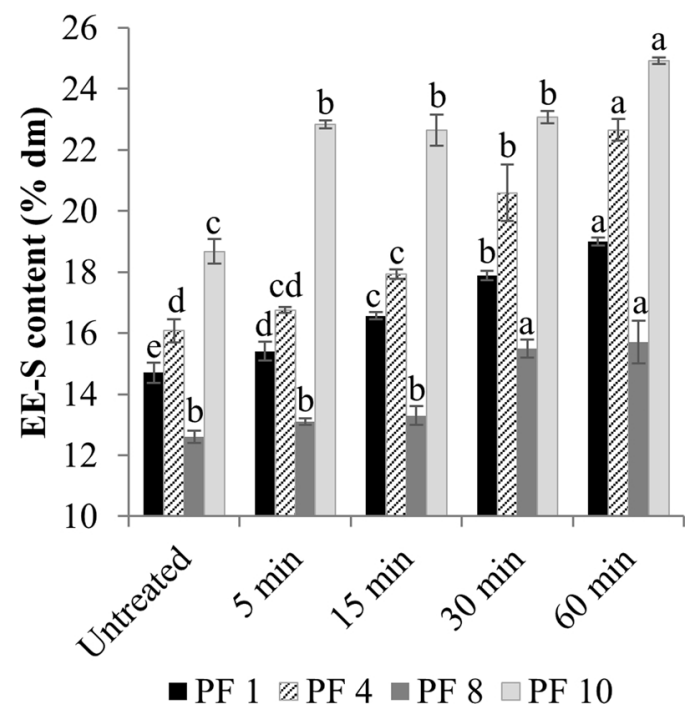

Fig. 4. Extractable extracellular starch (EE-S) content of untreated and ball milled potato flakes (PFs). Mean values for the same sample differ significantly ( $p<0.05$, Tukey's test) when not sharing the same lower case letter.

Potato cell walls limit the release of starch molecules from the cellular matrix since parenchyma cell walls hamper starch swelling and, hence, starch leaching.

Fig. 5A shows the HPSEC profiles of debranched EE-S extracted from untreated PFs and PFs ball milled for $60 \mathrm{~min}$. In general, ball milling increased EE-AP content by about $30 \%$. However, ball milling of PFs 1,8 and 10 did not release AM from the cellular matrix. Only in the case of PF 4 did ball milling during $60 \mathrm{~min}$ lead to a higher relative EEAM content (20.8 AU vs. 13.9 AU), which was mainly due to a higher extractability of EE-AM $150-1500$ (12.8 AU vs. 7.9 AU). Ball milling thus mainly increased the extractability of short AM molecules.

In a next step, PFs were incubated with cellulase. Although the EE-S content of the control samples increased by $15-50 \%$ merely as a result of the incubation (Fig. 6), addition of cellulase further increased the EE$S$ content of all PFs studied at every incubation time. After $6 \mathrm{~h}$ of incubation, enzymatic cell wall breakdown had significantly increased the EE-S content of PF 1, 4, 8 and 10 from 16.3 to $23.6 \% \mathrm{dm}$, from 13.4 to $24.8 \% \mathrm{dm}$, from 9.6 to $16.3 \% \mathrm{dm}$ and from 20.5 to $26.6 \% \mathrm{dm}$, respectively. The HPSEC profiles (Fig. 5B) of EE-S extracted from control and cellulase treated PFs after $6 \mathrm{~h}$ of incubation showed that cell wall hydrolysis mainly had increased the relative EE-AP content. Cellulase
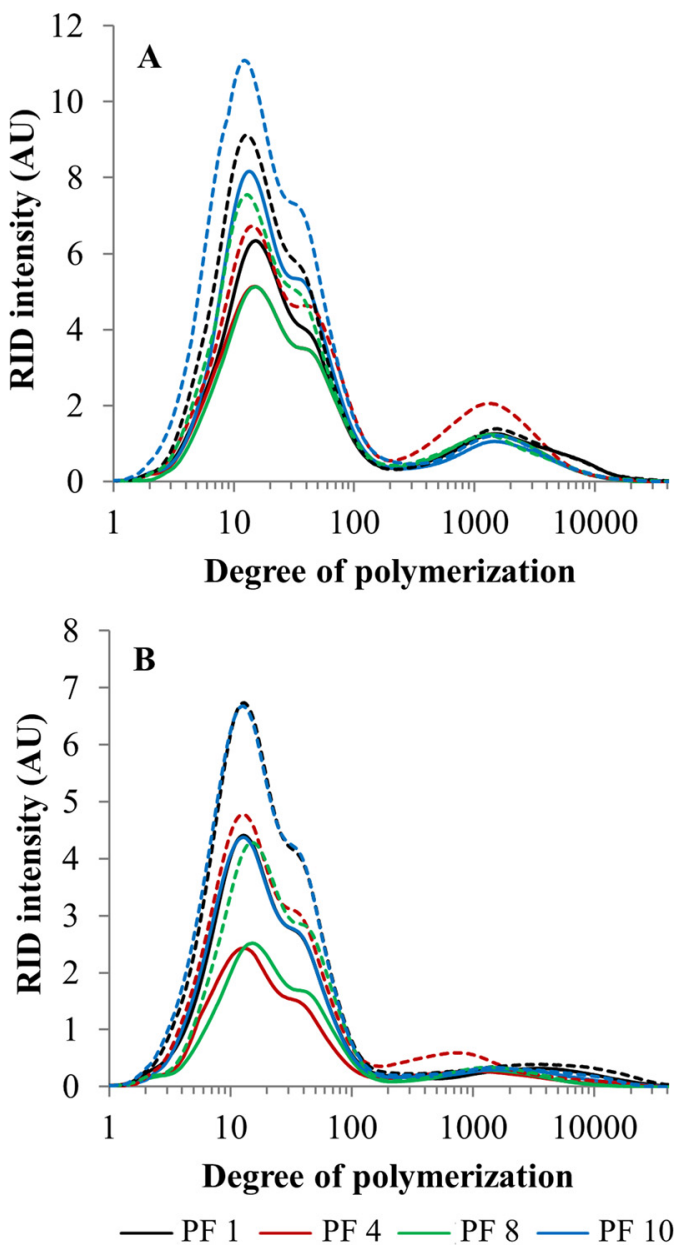

Fig. 5. High performance size exclusion chromatography (HPSEC) profiles of debranched extractable extracellular starch (EE-S) of (A) untreated (full line) and ball milled (60 min, dotted line) potato flakes (PFs) and (B) control (full line) and cellulase treated $(0.10 \mathrm{U}$ per $\mathrm{g}$ dry matter, incubation time $6 \mathrm{~h}$, dotted line) PFs.

treatment resulted in significantly higher relative EE-AM contents only for PF 1 (increase from 3.9 to $4.7 \mathrm{AU}$ ) and PF 4 (increase from 3.4 to 6.2 $\mathrm{AU})$. In the case of PF 1, enzymatic cell wall breakdown mainly increased the relative amount of $\mathrm{EE}-\mathrm{AM}>1500$ (3.0 AU vs. $2.4 \mathrm{AU}$ ) while 

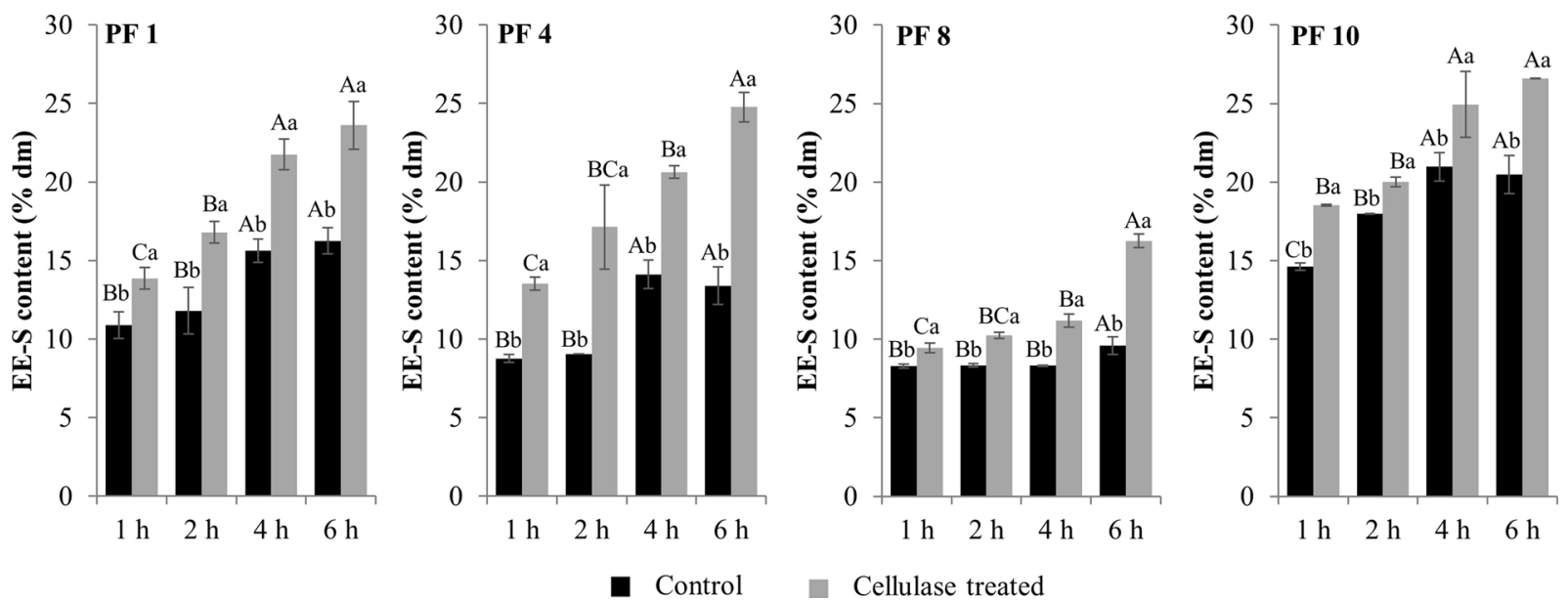

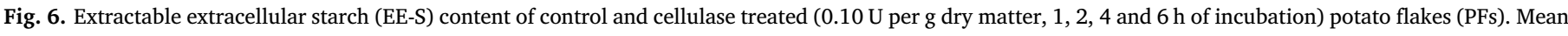

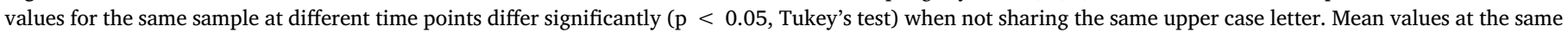
time point (with or without cellulase treatment) differ significantly ( $\mathrm{p}<0.05$, Tukey's test) when not sharing the same lower case letter.

for PF 4, a higher relative EE-AM $150-1500$ content was observed (4.6 AU vs. $2.2 \mathrm{AU})$.

\subsection{Pasting properties}

Fig. 7 shows the RVA profiles $(8.0 \% \mathrm{dm})$ of (A) untreated and ball milled PF suspensions and (B) PF suspensions with and without (control) addition of cellulase. The pasting properties of all $8.0 \% \mathrm{dm} \mathrm{PF}$ suspensions were measured in a concentration regime exceeding their $\mathrm{C}^{*}$ at $50^{\circ} \mathrm{C}$ (results not shown) and thus under conditions where the viscosity development is influenced by both PF swelling and rigidity (Eerlingen et al., 1997; Steeneken, 1989). Prior ball milling of PFs gradually increased PV values (Fig. 3). Milling during 60 min resulted in significantly higher PV readings (2130 vs. $1470 \mathrm{mPas}, 2140$ vs. $1080 \mathrm{mPa}$ s, 1990 vs. $1715 \mathrm{mPa}$ and 1570 vs. $1200 \mathrm{mPa}$ s for PFs 1, 4, 8 and 10, respectively). Treating PFs with cellulase increased PV values with 26\% (PF 8) to 78\% (PF 4) (Table 3) but did not alter PF mean particle size. This indicated that especially PF swelling properties rather than their mean particle sizes play a key role in the instant viscosity development of the PF suspensions. At the same time, both physical and enzymatic cell wall opening led to substantially larger viscosity breakdown of the PF suspensions in the RVA model. Potato starch is subject to larger viscosity breakdown than cereal starches due to its high SP and the accompanying disintegration of the granules (Gomand, Lamberts, Visser et al., 2010; Waterschoot, Gomand, Willebrords, Fierens, \& Delcour, 2014). Cell wall breakdown of PFs probably allows starch granule remnants to swell to a larger extent and their disintegration is held responsible for the large viscosity breakdown of the treated PFs.

Finally, Table 2 shows that the CPVs of ball milled PFs were significantly higher than those of their untreated counterparts. For PFs 1, 8 and 10, however, the relative increase in CPV values amounted to less than $10 \%$ as a result of 60 min of ball milling while, for PF 4 , a $30 \%$ increase was observed. Similar to what was the case for ball milling, only PF 4 showed a significantly higher CPV when cellulase was added to the suspension ( 985 vs. $880 \mathrm{mPa}$ ). Gomand, Lamberts, Visser et al. (2010) reported that the AM content of various potato starches is related to the $\mathrm{CPV}$ of suspensions thereof when analyzed at levels exceeding $C^{*}$. The large increase in CPV values of PF 4 upon cell wall breakdown is most likely due to pronounced increase in relative EE-AM content. Moreover, the increased level of EE-AM was mainly due to higher levels of EE-AM $\mathrm{AM}_{150-1500}$. These results provide further evidence that especially relatively short AM molecules contribute to the gelation of PF suspensions (see Section 3.1). Liu et al. (2017) recently showed that the fine structure of pre-gelatinized rice starch strongly impacts its pasting and gelation properties in RVA models suggesting that a decrease in AP MW during pre-gelatinization would hinder AM association during cooling and, hence, hamper gel formation. Moreover, Li, Prakash, Nicholson, Fitzgerald, and Gilbert (2016) studied the impact of AM fine structure on the textural properties of cooked rice and found a positive relationship between the amount of short AM molecules and product hardness. We here advance the current state of the art by providing direct evidence that especially short AM molecules play a major role in gel formation of pre-gelatinized starches probably because they are more mobile than larger such molecules and thus readily associate with each other upon cooling.

\section{Conclusions}

In the present work, the properties of PFs governing their viscosifying potential were unraveled. We showed that potato parenchyma cell walls inhibit instant swelling of the pre-gelatinized starch enclosed in the cellular matrix of PFs and that they hamper the leaching of starch from the cells directly resulting in lower PVs and CPVs in an RVA model system. Partial cell wall opening significantly increased the SP of PFs and, hence, their instant viscosity development. Higher PV values were accompanied by a substantially larger viscosity breakdown since the starch granule remnants are more susceptible to degradation upon extensive swelling. At the same time, physical and enzymatic cell wall breakdown led to a substantial release of starch (mainly AP) from the cellular matrix. However, CPV values of PF suspensions were significantly related to the amount and degree of polymerization of EEAM. Higher levels of short EE-AM molecules positively impacted gel formation. Taken together, partial opening of potato cell walls improves the viscosity development and gel forming capacity of PFs and can expand their applicability in instant food concepts such as instant soups, sauces and fried or extruded potato-based snacks. 
$\mathbf{A}$
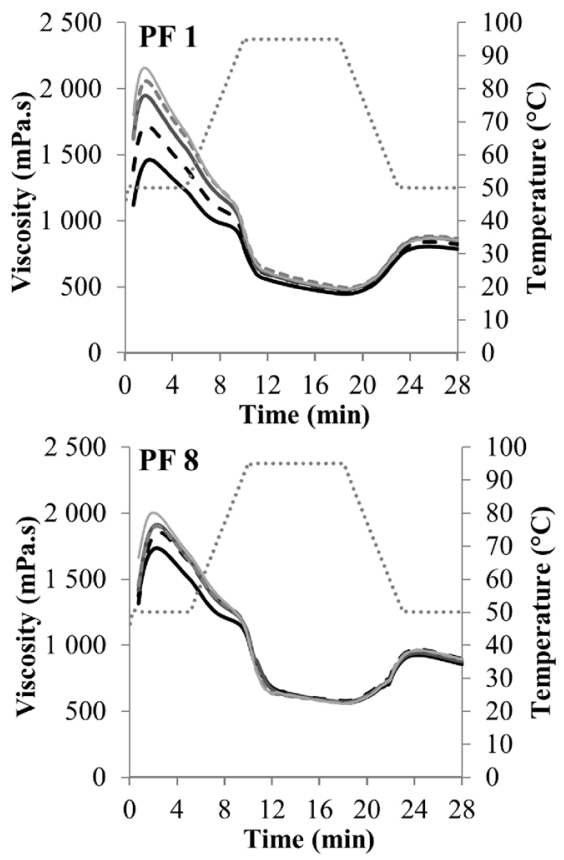

- Untreated -.--- $30 \mathrm{~min}$

B
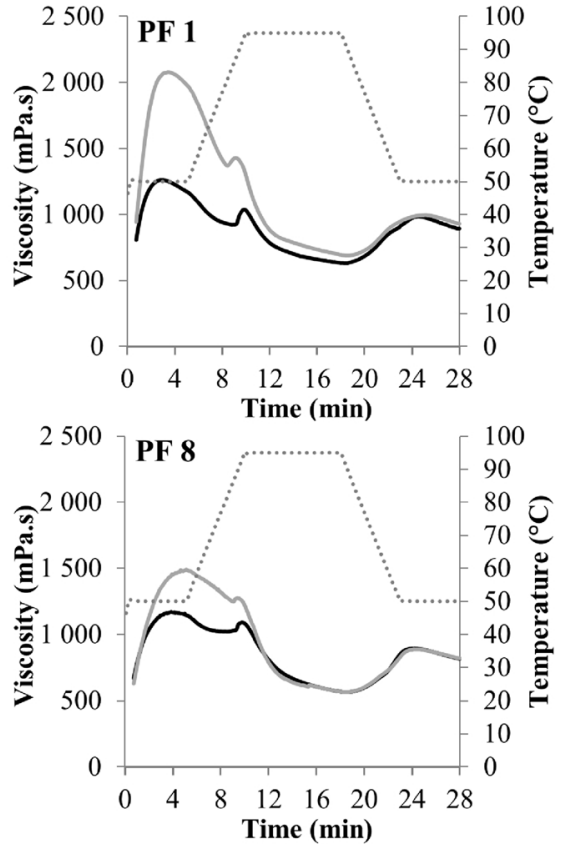

Control
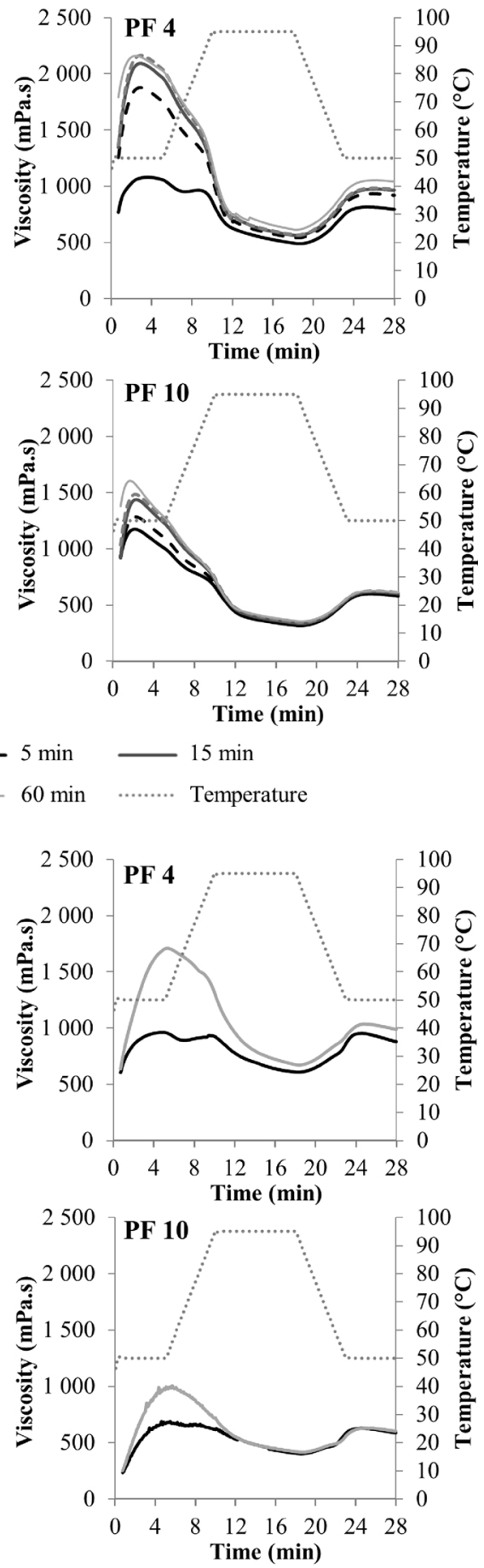

Cellulase treated

Temperature

Fig. 7. Rapid Visco Analyzer (RVA) profiles of $8.0 \%$ dry matter (dm) suspensions of (A) untreated and ball milled potato flakes (PFs) and (B) PFs with or without (control) addition of $0.10 \mathrm{U}$ cellulase per $\mathrm{g}$ dm flakes.

\section{Acknowledgements}

The Agentschap Innoveren \& Ondernemen - Vlaanderen (VLAIO) (Brussels, Belgium) and the Kellogg Company (Battle Creek, MI, USA) are thanked for financial support. Nele Schoonens is kindly acknowledged for excellent technical assistance. Fruitful discussions with K. De Rop (Kellogg Company) are highly appreciated. K. Brijs acknowledges the industrial Research Fund (KU Leuven, Leuven, Belgium) for his position as industrial research manager. J.A. Delcour is W.K. Kellogg Chair in Cereal Science and Nutrition at KU Leuven.

\section{Appendix A. Supplementary data}

Supplementary data associated with this article can be found, in the online version, at https://doi.org/10.1016/j.carbpol.2018.04.057.

\section{References}

AACC-I (1999). Approved methods of the American Association of cereal chemists (11th ed.). St. Paul, MN, USA: AACC International.

AOAC (1995). Official methods of analysis of the Association of Official Analytical Chemists (16th ed.). Washington, DC, USA: The Association of Official Analytical Chemists. 
Ahmed, A. E. R., \& Labavitch, J. M. (1978). A simplified method for accurate determination of cell wall uronide content. Journal of Food Biochemistry, 1(4), 361-365.

Alvarez, M. D., \& Canet, W. (1999). Rheological properties of mashed potatoes made from dehydrated flakes: Effect of ingredients and freezing. European Food Research and Technology, 209(5), 335-342.

Anastasiades, A., Thanou, S., Loulis, D., Stapatoris, A., \& Karapantsios, T. D. (2002) Rheological and physical characterization of pregelatinized maize starches. Journal of Food Engineering, 52(1), 57-66.

Bergthaller, W. (2004). Developments in potato starches. In A. C. Eliasson (Ed.). Starch in food: Structure, function and applications (pp. 241-257). Woodhead Publishing.

Blumenkrantz, N., \& Asboe-Hansen, G. (1973). New method for quantitative determination of uronic acids. Analytical Biochemistry, 54(2), 484-489.

Bordoloi, A., Kaur, L., \& Singh, J. (2012). Parenchyma cell microstructure and textura characteristics of raw and cooked potatoes. Food Chemistry, 133(4), 1092-1100.

Bosmans, G. M., Lagrain, B., Deleu, L. J., Fierens, E., Hills, B. P., \& Delcour, J. A. (2012). Assignments of proton populations in dough and bread using NMR relaxometry of starch, gluten, and flour model systems. Journal of Agricultural and Food Chemistry, 60(21), 5461-5470.

Buléon, A., Colonna, P., Planchot, V., \& Ball, S. (1998). Starch granules: Structure and biosynthesis. International Journal of Biological Macromolecules, 23(2), 85-112.

Chiu, C., \& Solarek, D. (2009). Modification of starches. In J. BeMiller, \& R. Whistler (Eds.). Starch: Chemistry and technology (pp. 629-648). (3rd ed.). New York, USA: Academic Press.

Chung, H.-J., \& Liu, Q. (2009). Impact of molecular structure of amylopectin and amylose on amylose chain association during cooling. Carbohydrate Polymers, 77(4), 807-815.

Courtin, C. M., Van den Broeck, H., \& Delcour, J. A. (2000). Determination of reducing end sugar residues in oligo- and polysaccharides by gas-liquid chromatography. Journal of Chromatography A, 866(1), 97-104.

de Boer, G. B. J., de Weerd, C., Thoenes, D., \& Goossens, H. W. J. (1987). Laser diffraction spectrometry: Fraunhofer diffraction versus Mie scattering. Particle \& Particle Systems Characterization, 4(1-4), 14-19.

Delcour, J. A., \& Hoseney, R. C. (2010). Principles of cereal science and technology (3th ed.). St. Paul, MN, USA: AACC Interntional Press.

Dries, D. M., Gomand, S. V., Goderis, B., \& Delcour, J. A. (2014). Structural and thermal transitions during the conversion from native to granular cold-water swelling maize starch. Carbohydrate Polymers, 114, 196-205.

Dries, D. M., Gomand, S. V., Delcour, J. A., \& Goderis, B. (2016). V-type crystal formation in starch by aqueous ethanol treatment: The effect of amylose degree of polymerization. Food Hydrocolloids, 61, 649-661.

Dries, D. M., Gomand, S. V., Pycarelle, S. C., Smet, M., Goderis, B., \& Delcour, J. A. (2017). Development of an infusion method for encapsulating ascorbyl palmitate in V-type granular cold-water swelling starch. Carbohydrate Polymers, 165, 229-237.

Dries, D. M., Knaepen, L., Goderis, B., \& Delcour, J. A. (2017). Encapsulation of the antioxidant ascorbyl palmitate in V-type granular cold-water swelling starch affects the properties of both. Carbohydrate Polymers, 165, 402-409.

Dubois, M., Gilles, K. A., Hamilton, J. K., Rebers, P. A., \& Smith, F. (1956). Colorimetric method for determination of sugars and related substances. Analytical Chemistry, 28(3), 350-356.

Eerlingen, R. C., Jacobs, H., Block, K., \& Delcour, J. A. (1997). Effects of hydrothermal treatments on the rheological properties of potato starch. Carbohydrate Research, 297(4), 347-356.

Escher, F., Rotach, P., Schweingruber, P., \& Solms, J. (1979). A modified method for determining the blue value index of instant mashed potato products. LebensmittelWissenschaft Und-Technologie, 12, 27-30.

Gidley, M. J., \& Bulpin, P. V. (1989). Aggregation of amylose in aqueous systems: The effect of chain length on phase behavior and aggregation kinetics. Macromolecules, 22(1), 341-346.

Gisaw, Y., Asquith, T. N., Lai, O. S., Villagran, M. D., \& Cole, B. R. (2003). US Patent No. $6,558,730 \mathrm{~B} 1$

Gomand, S. V., Lamberts, L., Derde, L. J., Goesaert, H., Vandeputte, G. E., Goderis, B., et al. (2010). Structural properties and gelatinisation characteristics of potato and cassava starches and mutants thereof. Food Hydrocolloids, 24(4), 307-317.

Gomand, S. V., Lamberts, L., Visser, R. G. F., \& Delcour, J. A. (2010). Physicochemical properties of potato and cassava starches and their mutants in relation to their structural properties. Food Hydrocolloids, 24(4), 424-433.

Jane, J., \& Seib, P. A. (1991). U.S. Patent No. 5, 057, 157.

Kim, E.-J., \& Kim, H.-S. (2015a). Influence of pectinase treatment on the physicochemical properties of potato flours. Food Chemistry, 167, 425-432.

Kim, E.-J., \& Kim, H.-S. (2015b). Physicochemical properties of dehydrated potato parenchyma cells with ungelatinized and gelatinized starches. Carbohydrate Polymers,
$117,845-852$.

Kim, D., \& Yoo, B. (2014). Comparison of rheological properties of native and pregelatinized potato starches. Food Science and Biotechnology, 23(3), 787-790.

Lamberti, M., Geiselmann, A., Conde-Petit, B., \& Escher, F. (2004). Starch transformation and structure development in production and reconstitution of potato flakes. Food Science \& Technology, 37, 417-427.

Li, H., Prakash, S., Nicholson, T. M., Fitzgerald, M. A., \& Gilbert, R. G. (2016). The importance of amylose and amylopectin fine structure for textural properties of cooked rice grains. Food Chemistry, 196, 702-711.

Li, H., Fitzgerald, M. A., Prakash, S., Nicholson, T. M., \& Gilbert, R. G. (2017). The molecular structural features controlling stickiness in cooked rice, a major palatability determinant. Scientific Reports, 7, 43713.

Liu, Y., Chen, J., Luo, S., Li, C., Ye, J., Liu, C., et al. (2017). Physicochemical and structural properties of pregelatinized starch prepared by improved extrusion cooking technology. Carbohydrate Polymers, 175, 265-272.

Majzoobi, M., Kaveh, Z., Blanchard, C. L., \& Farahnaky, A. (2015). Physical properties of pregelatinized and granular cold water swelling maize starches in presence of acetic acid. Food Hydrocolloids, 51, 375-382.

Mason, W. R. (2009). Starch use in foods. In J. BeMiller, \& R. Whistler (Eds.). Starch: chemistry and technology (pp. 745-788). New York, USA: Academic Press.

McGrane, S. J., Mainwaring, D. E., Cornell, H. J., \& Rix, C. J. (2004). The role of hydrogen bonding in amylose gelation. Starch-Stärke, 56(3-4), 122-131.

Rajagopalan, S., \& Seib, P. A. (1992). Granular cold-water-soluble starches prepared at atmospheric pressure. Journal of Cereal Science, 16(1), 13-28.

Singh, N., Singh, J., Kaur, L., Sodhi, N. S., \& Gill, B. S. (2003). Morphological, thermal and rheological properties of starches from different botanical sources. Food Chemistry, 81(2), 219-231.

Steeneken, P. A. M. (1989). Rheological properties of aqueous suspensions of swollen starch granules. Carbohydrate Polymers, 11(1), 23-42.

Svegmark, K., \& Hermansson, A.-M. (1991). Distribution of amylose and amylopectin in potato starch pastes: Effects of heating and shearing. Food Structure, 10, 117-129.

Takeda, Y., \& Hizukuri, S. (1982). Location of phosphate groups in potato amylopectin. Carbohydrate Research, 102(1), 321-327.

Takeda, Y., Shirasaka, K., \& Hizukuri, S. (1984). Examination of the purity and structure of amylose by gel-permeation chromatography. Carbohydrate Research, 132(1), 83-92.

Takeda, Y., Shibahara, S., \& Hanashiro, I. (2003). Examination of the structure of amylopectin molecules by fluorescent labeling. Carbohydrate Research, 338(5), 471-475.

Tan, I., Wee, C. C., Sopade, P. A., \& Halley, P. J. (2004). Investigation of the starch gelatinisation phenomena in water-glycerol systems: Application of modulated temperature differential scanning calorimetry. Carbohydrate Polymers, 58(2), 191-204.

Tester, R. F., \& Morrison, R. (1990). Swelling and gelatinization of cereal starches. 1. Effects of amylopectin, amylose and lipids. Cereal Chemistry, 67, 551-557.

Tester, R. F., Karkalas, J., \& Qi, X. (2004). Starch-composition, fine structure and architecture. Journal of Cereal Science, 39(2), 151-165.

Tzoumaki, M. V., Moschakis, T., Kiosseoglou, V., \& Biliaderis, C. G. (2011). Oil-in-water emulsions stabilized by chitin nanocrystal particles. Food Hydrocolloids, 25(6), 1521-1529.

van Dijk, C., Fischer, M., Beekhuizen, J.-G., Boeriu, C., \& Stolle-Smits, T. (2002). Texture of cooked potatoes (Solanum tuberosum). 3. Preheating and the consequences for the texture and cell wall chemistry. Journal of Agricultural and Food Chemistry, 50(18), 5098-5106.

van Marle, J. T., Stolle-Smits, T., Donkers, J., van Dijk, C., Voragen, A. G. J., \& Recourt, K. (1997). Chemical and microscopic characterization of potato (Solanum tuberosum L.) cell walls during cooking. Journal of Agricultural and Food Chemistry, 45(1), 50-58.

Villagran, M.D., Beverly, D.J., Williamson, L., (2011). U.S. Patent No. 7, 998, 522 B2.

Wang, K., Hasjim, J., Wu, A. C., Henry, R. J., \& Gilbert, R. G. (2014). Variation in amylose fine structure of starches from different botanical sources. Journal of Agricultural and Food Chemistry, 62(19), 4443-4453.

Waterschoot, J., Gomand, S. V., Willebrords, J. K., Fierens, E., \& Delcour, J. A. (2014). Pasting properties of blends of potato, rice and maize starches. Food Hydrocolloids, 41, 298-308.

Yadav, A. R., Guha, M., Tharanathan, R. N., \& Ramteke, R. S. (2006). Influence of drying conditions on functional properties of potato flour. European Food Research and Technology, 223(4), 553-560.

Zhang, B., Dhital, S., Haque, E., \& Gidley, M. J. (2012). Preparation and characterization of gelatinized granular starches from aqueous ethanol treatments. Carbohydrate Polymers, 90(4), 1587-1594. 